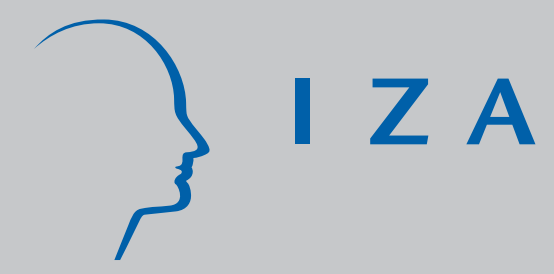

IZA DP No. 1878

One or Many Knowledge Production Functions? Mapping Innovative Activity Using Microdata

Andrea Conte

Marco Vivarelli

December 2005 


\title{
One or Many Knowledge Production Functions? Mapping Innovative Activity Using Microdata
}

\author{
Andrea Conte \\ University of Turin \\ and Max Planck Institute of Economics, Jena \\ Marco Vivarelli \\ Catholic University of Piacenza, \\ Max Planck Institute of Economics, Jena, \\ CSGR, Warwick University and IZA Bonn
}

Discussion Paper No. 1878

December 2005

\author{
IZA \\ P.O. Box 7240 \\ 53072 Bonn \\ Germany \\ Phone: +49-228-3894-0 \\ Fax: +49-228-3894-180 \\ Email: iza@iza.org
}

Any opinions expressed here are those of the author(s) and not those of the institute. Research disseminated by IZA may include views on policy, but the institute itself takes no institutional policy positions.

The Institute for the Study of Labor (IZA) in Bonn is a local and virtual international research center and a place of communication between science, politics and business. IZA is an independent nonprofit company supported by Deutsche Post World Net. The center is associated with the University of Bonn and offers a stimulating research environment through its research networks, research support, and visitors and doctoral programs. IZA engages in (i) original and internationally competitive research in all fields of labor economics, (ii) development of policy concepts, and (iii) dissemination of research results and concepts to the interested public.

IZA Discussion Papers often represent preliminary work and are circulated to encourage discussion. Citation of such a paper should account for its provisional character. A revised version may be available directly from the author. 


\section{ABSTRACT \\ One or Many Knowledge Production Functions? Mapping Innovative Activity Using Microdata ${ }^{*}$}

This paper discusses the determinants of three alternative measures of innovative output by looking at firm's own formal R\&D activities and at the acquisition of external technology (TA) in its embodied and disembodied components. These input-output relationships are also discussed by distinguishing between small and large firms and those belonging to low-tech and high-tech sectors. The empirical analysis focuses on the Italian industrial sector over the period 1998-2000, using a subsample of 2,949 firms from the third European Community Innovation Survey (CIS 3). A bivariate probit analysis framework is used to investigate the determinants of product and process innovations, while truncated regressions are used to discuss innovation intensity. This paper also discusses an alternative test procedure that permits an extension of Cragg's test in the analysis of survey data with weighted observations. Results show that R\&D is strictly linked to product innovation, while TA is crucial in fostering process innovation; however, both inputs increase a firm's innovative intensity. Significant evidence is also found that small firms and firms belonging to low-tech sectors rely more on the acquisition of external technologies and on cooperation agreements, while larger firms in high-tech sectors rely more on their own formal R\&D.

JEL Classification: $\quad$ O31

Keywords: $\quad$ R\&D, product and process innovation, embodied technical change, CIS 3, bivariate probit, Cragg's test

Corresponding author:

Marco Vivarelli

Facoltà di Economia

Università Cattolica

Via Emilia Parmense 84

I-29100 Piacenza

Italy

Email: marco.vivarelli@unicatt.it

\footnotetext{
* The authors would like to thank Giovanni Seri and the ADELE Laboratory at ISTAT in Rome for the provision of $\mathrm{CIS} 3$ data. Previous versions of this paper have been presented at CNR-Rome, University of Turin and the Max Planck Institute of Economics in Jena; comments by participants at these seminars were extremely useful.
} 


\section{Introduction}

Technological change is the driving force of economic development. However, innovation is not randomly distributed among firms but is rather the outcome of successful strategies, investment and relationships which firms actively seek and develop in the market.

This paper discusses the sources of innovation at firm level; namely R\&D activities and the acquisition of technology (TA) both as embodied (machinery and equipment) and disembodied. This input-output relationship points to the concept of the "Knowledge Production Function" (KPF) (Griliches, 1979) as being a feasible tool for describing the trasformation process that runs from innovative inputs to innovative outputs.

While most previous microeconometric research has focused on the R\&D-Innovation-Productivity chain (see next section), few studies have explicitly discussed the role of TA and possible differences in the KPF across sectors and among firms of different size. By using microdata from the European Community Innovation Survey 3 (CIS 3) for the Italian industrial sector, the main novelty of this paper lies precisely in its investigation of whether R\&D and TA lead to significant differences in determining innovative output in firms of different size and belonging to different sectors. In addition, the important distinction between product and process innovation will also be taken into account, the basic hypothesis being that small firms and traditional sectors (mainly characterised by process innovation) should rely more on the external acquisition of technology, while their larger counterparts in high-tech sectors (mainly characterised by product innovation) should rely more on formal $R \& D^{1}$.

A second novelty of this paper is related to the econometric methodology adopted (see Section 4). First, the issue of whether the innovative propensity of a firm and the intensity of its innovative effort should be modelled separately by two independent equations is discussed. While Cragg's test (Cragg, 1971) is easily implemented when empirical research deals with datasets made up of unweighted observations, the same test does not provide correct estimates in the case of survey data with weighted observations. Therefore this paper proposes a simple alternative procedure for testing a Tobit model specification against the alternative of a two-part model when dealing with weighted survey data such as that provided by CIS 3. Second, a simultaneous bivariate approach is adopted for modelling the introduction of product and process innovation by firms.

The remainder of the paper is organised as follows: a discussion of the theoretical framework on which this work is based (Section 2) is followed by the description of data and indicators used in the empirical analysis (Section 3) and by the discussion of the adopted econometric methodology (Section 4). Subsequently, the empirical outcomes derived from the descriptive analysis (Section 5) and the econometric estimates (Section 6) are discussed. Section 7 concludes the paper by briefly summarising the main findings obtained.

\section{The literature}

Previous economic literature has adopted $R \& D$ and patents as a starting point for the analysis of innovative activities across economies, industries and firms. In particular, the relationship between innovative inputs and outputs explicitly appears as one of the components of those analyses

\footnotetext{
${ }^{1}$ Beyond R\&D and TA, empirical analysis in this paper includes the belonging to an industrial group, and cooperation agreements pursued both through market interaction and through links with research institutions (such as universities, research centres and consultancies) as additional explanatory variables of firm's innovativeness.
} 
whose main target is to measure the returns on innovation. In this stream of literature, the first contribution to discuss the innovative input-output relationship was by Griliches (1979 and 1990), through a three-equation model in which one of the equations is what he called the Knowledge Production Function (KPF), a function intended to represent the transformation process leading from innovative inputs $(\mathrm{R} \& \mathrm{D})$ to innovative outputs (patents) ${ }^{2}$. Similarly, the KFP is also included in the four-equation model provided by Crepon et al. (1998) and Loof and Hesmati (2001).

The theoretical framework so far described has provided the background for understanding the link between innovative inputs and outputs and for the empirical assessment of this relationship. However, for the particular purpose of this paper, most of the previous empirical studies suffer from two main limitations.

First, the relationship between innovation inputs and innovation outputs is not their main focus but rather a secondary equation, ancillary to the authors' main purpose of proposing an extended version of a production function where capital and labour are augmented by the innovation term.

Second, the KPF is simplified as a link between R\&D and patents. Historically driven by relative availability with respect to other measures of innovation, the relationship between a firm's $R \& D$ investment and patenting activity leaves room today for a more comprehensive approach to the determinants of a firm's innovativeness. In particular, nowadays innovation surveys provide more precise and comprehensive measures of innovative outputs which overcome the serious limitations of patent data underlined by comprehensive literature ${ }^{3}$.

In addition, innovation surveys permit a better identification of the presence of any kind of innovation activity, and a distinction between product and process innovation. Consistently, different innovation outputs can be seen as the outcomes of several innovation inputs and not only as the consequence of R\&D investments ${ }^{4}$. For instance, the literature suggests that more complex product innovation generally relies on formal $\mathrm{R} \& \mathrm{D}^{5}$, while process innovation (where it is not easy to single out pure innovation, diffusion and imitation with any precision) is much more related to TA, both through the "embodied technical change" ${ }^{6}$ acquired by investment in new machinery and equipment and through the purchasing of external technology incorporated in licences, consultancies, know-how (Freeman, 1982; Freeman et al., 1982; Freeman and Soete, 1987).

This paper represents an attempt to open up this broader perspective. Once it has been recognized that innovative inputs are not confined to formal $R \& D$ and that innovative outputs can be measured by other (more satisfactory) indicators than patents, we pave the way to the analysis of firm and sector peculiarities in the KPF.

At the firm level, the assessment of the importance of firm's size for innovative activity dates back to Schumpeter. While small and newly established firms are expected to be innovators when

\footnotetext{
${ }^{2}$ The other two equations in Griliches' simultaneous model represent the production function (augmented by the innovation term) and the determinants of R\&D investment. See also Harhoff et al. (2003), Hall et al. (2004), Hall (2000), Hall (1996) and Mairesse and Mohen (2002).

${ }^{3}$ Patents turn out to be a very rough proxy of innovation for several reasons: 1) not all innovation is patented (firms generally prefer other ways of protecting their innovation, see Levin, Klevorick, Nelson and Winter, 1988); 2) patents are very rare among innovative small firms; 3) patents differ greatly in their importance; 4) firms in different sectors show very different propensities to patent (see Archibugi and Pianta, 1992; Patel and Pavitt, 1995).

${ }^{4}$ This broader perspective is also endorsed in methodological advice as to the collection of data regarding innovation; in particular, this is well represented by the shift from the R\&D-focused Frascati Manual ("Guidelines for the collection of R\&D data", first published in 1963) to the Oslo Manual in the 1990s (OECD, 1997).

${ }^{5}$ Among the few studies assessing the impact of innovation on productivity distinguishing between product and process innovations, Parisi et al. (2005) found robust and significant evidence that R\&D increases the likelihood of introducing product innovation.

${ }^{6}$ The embodied nature of technological progress and the effects related to its spread in the economy were originally discussed by Salter (1960); in particular, vintage capital models describe an endogenous process of innovation in which the replacement of old equipment is the main way through which firms update their own technologies.
} 
technological change is considered as a process of "creative destruction" (Schumpeter, 1934), when stressing the process of "creative accumulation" he calls for large and established firms to take a leading role in the innovative process (Schumpeter, 1942).

Several arguments sustain the view that larger firms are more innovative. First, larger firms are not affected by liquidity constraints since they have both easier access to external finance and larger internal funds to support innovative activities; second, large corporations are characterised by a higher degree of diversification that helps them to deal with the uncertainty of innovation; third, larger firms possess a higher degree of market power and so enjoy a higher degree of "appropriability"; in fact, the "efficiency effect" increases firms' innovative activity because it frees them from competitive pressure when exploiting the returns on their innovations (Gilbert and Newbery, 1982). In addition, Mairesse and Mohen (2002) underline scale economies and the differences in the organization of work that make larger firms more innovative.

However, not all innovative firms are large corporations. Indeed, the economic literature supports the hypothesis that small firms face a different technological and economic environment from large firms with respect to innovative activities (Winter, 1984; Acs et al., 1994). For instance, small firms appear to be in a better position in the introduction and diffusion of process innovation rather than in promoting new products, where the disadvantages discussed above are more obvious (see Pavitt, 1984; Acs and Audretsch, 1988 and 1990).

If we shift our attention to innovative inputs, Cohen and Klepper (1996) provide stylized facts supporting the view that the likelihood of a firm carrying out R\&D increases with size. However, $R \& D$ does not represent the sole input through which firms can produce some innovative outcomes. While the financial and competitive reasons discussed above can hamper an R\&D-based innovative strategy for small firms, it seems much easier for them to rely on the market and choose "to buy" instead of "to make" technology (Acs and Audretsch, 1990). One of the hypotheses to be tested in this paper is therefore that innovation outcome in small firms should rely more on TA rather than on formal R\&D.

The sector to which a firm belongs represents another important analytical level for understanding the differences in innovative processes. The two alternative patterns of technological change stressed according to the Schumpeterian tradition - namely creative destruction or creative accumulation - have an obvious impact on industry dynamics (Nelson and Winter, 1982; Winter, 1984; Dosi, 1988). Firms face sector-specific technological "opportunities" and "appropriabilities" which respectively "push" and "pull" their innovative activity. Moreover, industries are characterised by different patterns in the selection process and in interaction among firms (Malerba and Orsenigo, 1996; Breschi et al., 2000; Malerba, 2002). Consequently, firms adapt their innovative strategy to their own particular economic environment by choosing the most effective combination of innovative inputs and outputs. In doing so, they distribute economic resources between formal $R \& D$ investment, technological change embodied in machinery and equipment, purchasing of external know how and licenses. For instance, in traditional sectors characterized by low technological opportunities, cost-cutting process innovation and a relevant presence of small firms, one would expect TA to have a dominant role ${ }^{7}$, while in high-tech sectors one would expect formal R\&D investment to have an important role.

\footnotetext{
${ }^{7}$ On the peculiarities of the Italian case, see Santarelli and Sterlacchini, 1990: the authors point out the important role of embodied technological change for small firms operating in traditional and mature sectors such as textile, wood and furniture, shoes, etc.
} 


\section{Dataset and Indicators}

This paper uses firm-level data drawn from the CIS 3. The entire sample amounts to 15,512 firms, of which 9,478 in the industrial sectors, and covers the period 1998-2000. This survey was conducted by ISTAT (Italian Institute of Statistics) in 2002 and it is representative of the entire Italian population of firms with more than 10 employees and active at December 31st, $2000^{8}$.

The CIS 3 dataset adopts a weighting procedure that relates the sample of firms interviewed to the entire population ${ }^{9}$ (ISTAT, 2004). Weights in CIS-like surveys indicate the inverse of the probability that the observation is sampled. They are used when selection probabilities in the sample differ across units, and therefore each observation in the survey represents a different number of units in the population. Weights are assigned according to the reciprocals of sampling probabilities because firms with low (high) probabilities of selection represent larger (smaller) numbers of firms in the population. Therefore, sampling weights ensure that each group of firms is properly represented and correct for sample selection. Moreover, sampling weights help in reducing heteroscedasticity commonly arising when analysis focuses on survey data ${ }^{10}$.

This paper focuses on a sub-sample of firms obtained through the following procedure: the first step was the exclusion of firms not belonging to the industrial sector; then, all firms in the original CIS 3 dataset that were either newborn or had recorded a turnover variation of at least $10 \%$ due to $\mathrm{M} \& \mathrm{~A}$ were excluded from the analysis ${ }^{11}$. At this point, the dataset included 8,610 innovative and non-innovative firms. Given the structure of the statistical questionnaire and our research purposes, four classes of firms were identified: 1) innovative firms as regards both input and output ${ }^{12}$; 2) non-innovative firms (the opposite of 1 ); 3) firms that declared the introduction of innovation but no innovative inputs; 4) firms with positive innovative expenditure but with innovative projects still in progress or stopped ${ }^{13}$. An empirical analysis aimed at verifying the

\footnotetext{
${ }^{8}$ The sample is representative at the sector level (Ateco 91 classification) and at the firm size level. The theoretical sample originally included 29,245 firms with respect to a total population of 164,593 firms. The number of respondents was $53 \%$, so determining the sample size of 15,512 firms. CIS 3 dataset supplies cross sectional data on firms' features, their innovative inputs and outcomes over a three-year period. The unavailability of panel data might represent an obstacle because of the possible non-simultaneity between firms' innovative efforts and their actual outcomes. However, on the one hand dealing with a three-year period should mitigate this problem, while on the other hand various studies have shown both a great deal of viscosity in innovation data at firm level (Brouwer and Kleinknecht, 1996) and short lags between innovative inputs and outputs (Griliches, 1995).

${ }^{9}$ Firm selection was carried out through a "one step stratified sample design". The sample in each stratum was selected with equal probability and without reimmission. The stratification of the sample was based on the following three variables: firm size, sector and regional location. Technically, in the generic stratum $h$, the random selection of $n_{h}$ sample observations among the $N_{h}$ belonging to the entire population was realised through the following procedure:

- a random number in the interval 0-1 was attributed to each $N_{h}$ population unit;

- $N_{h}$ population units were sorted by increasing values of the random number;

- units in the first $n_{h}$ positions in the order previously mentioned were selected.

Estimates obtained from the selected sample are very close to the actual values in the national population. The weighting procedure follows Eurostat and Oslo Manual (OECD, 1997) recommendations.

${ }^{10}$ Deaton (1997, pp. 44-45) provides a technical discussion on sampling weights, survey design and heteroscedasticity in survey data. When sampling weights are used, econometric software such as STATA automatically provides a robust variance estimation that adjusts for design characteristics so that standard errors and confidence intervals are correct.

${ }^{11}$ In both categories, diversifications, mergers and acquisitions may break the link between innovative inputs and outputs (link that must be studied within the borders of a single firms).

${ }^{12}$ A given firm was considered innovative if it declared an innovation output and if at least one of the expenditure items recorded in the CIS 3 questionnaire had a positive value (see Section 3.2). Firms that had recorded only marketing as an innovative activity were not considered as innovative (because of the secondary and delayed place marketing assumes in a firm's innovative process, Kline and Rosenberg, 1986).

${ }^{13}$ It is worth underlining that the CIS 3 questionnaire requires firms to declare their innovative inputs only if they have introduced innovation, whether they have innovative projects in progress and, finally, whether they have stopped
} 
relationship between innovative inputs and outputs has to focus only on innovative firms defined as those firms that have introduced innovation (that is product or process innovation) and that have declared a positive innovative expenditure. Therefore, we restricted our attention only to firms belonging to the first category ${ }^{14}$. The last step was the exclusion of those firms that had declared a $100 \%$ share of turnover due to innovative products. In fact, it is plausible to assume that a $100 \%$ value for this indicator reflects more a firm's inability to identify its own innovative result than a correct estimate. As a consequence of the procedure so far described, the final dataset included 2,949 innovative firms both on the input and output side ${ }^{15}$. It is worth noticing that using weights makes the sample fully representative of the total population of Italian innovative industrial firms.

\subsection{Innovative Outputs}

Innovative outputs can be distinguished with respect to their position in the innovation process. For instance, while patents are better defined as the outcome of the inventive process, product innovation properly represents the result of the market-oriented innovative process. However, even though product innovation is driven by demand considerations, it represents a pre-market result. In contrast, the share of sales deriving from innovative products (Mairesse and Mohnen, 2002) represents an ex-post result in which the market has positively welcomed the new products introduced by the firm (Barlet et al., 1998).

Taking these considerations and the interpretative background discussed in Section 2 into account, this paper uses three output indicators for the empirical analysis, namely the introduction of product innovation, the introduction of process innovation and the sales ratio of innovative products $^{16}$. While the first two indicators can be modelled in order to assess a firm's propensity to innovate, this sales-weighted measure of innovation is commonly used to indicate the intensity of innovation (Loof and Heshmati, 2002; Mairesse and Mohnen, 2002).

\subsection{Innovative Inputs}

Bearing the theoretical discussion presented in Section 2 in mind, two innovative inputs are used in this paper: expenditure in formal Research and Development (R\&D) and expenditures in Technology Acquisition (TA). The former includes both internally-performed R\&D (intra muros) and R\&D activities outsourced to other firms or research institutes (extra muros $R \& D$ ). The latter is the sum of embodied technological change (equipment and machinery) and the acquisition of external (disembodied) technology (know-how, projects and consultancies, licenses, software). Both R\&D data

\footnotetext{
any project related to the introduction of innovation.

${ }^{14}$ While the reasons for excluding firms in groups 2 and 4 are obvious, two main factors called for the exclusion of those firms that had declared positive percentages of their turnover deriving from the sale of innovative products and null innovative expenditures: first, their innovative outcome could have been simply the result of passive imitation; second, the actual lag between innovative inputs and outputs could have resulted in some firms exploiting today the one-spot innovative effort made in a previous period. Because of the cross sectional structure of CIS 3 data, this would have determined an unexplained variance of the output indicator.

${ }^{15}$ Specific research targets often require the selection of adequate sub-samples. For instance, Barlet et al. (1998) focus their econometric analysis only on firms introducing product innovation while examples of the censoring of extreme observations are provided by Hall and Mairesse (1995) and by Loof and Heshmati (2002).

${ }^{16}$ It is worth emphasising the causal link adopted in the questionnaire design; this link goes from product innovation to the sales ratio indicator in that only firms that have introduced product innovation can record a positive percentage of their turnover as being derived from product innovation.
} 
and TA data are flows in the questionnaire and as such they were used in the empirical analysis ${ }^{17}$.

\subsection{Dummy Variables}

CIS 3 provides further information on firms beyond their innovative activity. Econometric estimates in this paper will adopt some of these indicators as further controls and explanatory variables. Attention will be paid to a firm's belonging to an industrial group and to a cooperation agreement, distinguishing between agreements mediated by market relations (customers, suppliers or competitors) and agreements with research-focused partners such as universities and research laboratories. Mairesse and Mohen (2002) underline the expected innovative benefits due to easier access to (internal) finance and to the effect of intra-group knowledge spillovers for firms that are members of industrial groups. Similarly, several papers discuss the importance of cooperation agreements for the promotion of innovative activity. For instance, Feldman (1994) underlines the importance of knowledge complementarities that arise through cooperation for the promotion of innovative activities; Piga and Vivarelli (2004) provide a joint analysis of a firm's decision to carry out R\&D and to enter into an external R\&D relationship; Fritsch and Franke (2004) test the impact of cooperation agreements by using a KPF framework. The effect of cooperation agreements with research-focused partners recalls the importance of academic research for innovative activity as discussed by Jaffe (1989) and Acs et al. (1991); empirical confirmation of its importance for innovative activity is found by Loof and Heshmati (2002).

The occurrence of technological spillovers ${ }^{18}$ and the role of firm's "absorptive capacity" (Cohen and Levinthal, 1989; Griffith et al., 2003) may have different implications for the innovative activity of firms of different sizes and operating in different sectors. In particular, Acs et al. (1994) find that small firms are the favourite recipients of $\mathrm{R} \& \mathrm{D}$ activities generated in research-targeted institutions and that spillover effects are more important for small firms than for larger enterprises. In this framework, the hypothesis tested in this paper is that small firms and firms belonging to lowtech sectors - characterised by weaker endogenous resources and capabilities - should rely more on grouping and cooperation as pre-conditions to increase their likelihood of achieving process and /or product innovation.

Finally - when applicable - sectoral and regional dummies have been added to the econometric specifications.

\section{Econometric Issues}

\subsection{Model Specification}

Equation (1) describes the general specification adopted for the aggregate empirical test of the innovative input-output relationship:

\footnotetext{
${ }^{17}$ Crepon et al. (1998) underline the high cross-sectional correlation between stock and flow measures of innovative activity.

${ }^{18}$ Among the vast amount of literature discussing technological spillovers, examples of empirical analyses on the subject are provided by Bernstein and Nadiri (1989), Sterlacchini (1994) and Cassiman and Veugelers (2002).
} 


$$
\begin{gathered}
I N N O_{i}=\alpha_{i}+\beta_{1} R \& D_{i}+\beta_{2} T A_{i}+\beta_{3} C O R E S_{i}+\beta_{4} C O M K T_{i}+\beta_{5} G P_{i}+ \\
+\beta_{6} L O G(S I Z E)_{i}+\sum_{h} \gamma_{h} S E C T O R S_{h}+\sum_{h} \delta_{h} R E G I O N S_{h}+\varepsilon_{i}
\end{gathered}
$$

where $I N N O$ represents the innovative output and $R \& D$ and $T A$ indicate innovative inputs. Table 1 provides a description of the variables adopted for the econometric study.

\section{Table 1. List of Variables and Definitions}

\begin{tabular}{|l|l|}
\hline Output Variables \\
\hline PROD & Introduction of Product Innovation - Dummy variable \\
\hline PROC & Introduction of Process Innovation - Dummy variable \\
\hline TURNINN & Share of sales from innovative products over total turnover \\
\hline Input Variables \\
\hline RD & $\begin{array}{l}\text { R\&D: firm's expenditure in intra muros and extra muros activities; } \\
\text { R\&D normalised by total turnover }\end{array}$ \\
\hline TA & $\begin{array}{l}\text { Technology Acquisition: firm's expenditure for embodied and } \\
\text { external technology, normalised by total turnover }\end{array}$ \\
\hline Control Variables \\
\hline cores & Cooperation agreements with research institutions - Dummy variable \\
\hline comkt & Market cooperation agreements - Dummy variable \\
\hline gp & Belonging to an industrial group - Dummy variable \\
\hline Logsize & Log of firm's employees in year 2000 \\
\hline Sectoral and & Macro-Regional Dummies \\
\hline HT & High-tech Sectors \\
\hline LT & Low-tech Sectors \\
\hline Nwest & Northwest Italy \\
\hline Neast & Northeast Italy \\
\hline Central & Central Italy \\
\hline South & Southern Italy \\
\hline
\end{tabular}

Different dependent variables require different modelling strategies; in particular, the introduction of product innovation (or process innovation) is modelled by a probit model:

$$
P\left(y_{i}=1\right)=\Phi\left(X_{i} \beta_{1}\right)
$$

where $y_{i}=1$ indicates that the firm $i$ has introduced product innovation (or process innovation), $X_{i}$ is a row vector in the explanatory variables described in equation (1) and $\Phi$ is the standard normal cumulative distribution function.

As a consequence of the questionnaire's design, the sales-weighted measure of a firm's innovativeness (TURNINN) assumes a positive value only for firms that have introduced product innovation. 
This means that the density of $y_{i}$ conditional on being a non-limit (positive) observation follows a truncated normal distribution in $X_{i} \beta_{2}$ with a variance $\sigma^{2}$ and truncation at zero ${ }^{19}$ :

$$
f\left(y_{i} \mid y_{i}>0\right)=\frac{1}{\Phi\left(X_{i} \beta_{2} / \sigma\right)} \frac{1}{\sqrt{2 \pi} \sigma} \exp \left\{\frac{-1}{2 \sigma^{2}}\left(y_{i}-X_{i} \beta_{2}\right)^{2}\right\}
$$

\subsection{Tobit vs Two Part Model}

The first empirical step is to assess whether the chosen regressors for the econometric analysis show different impacts on the likelihood of introducing innovative products (probit model, PROD) and on the intensity of innovativeness measured by TURNINN (truncated model). As far as the latter is concerned, the Tobit model (Tobin, 1958) must be tested against an alternative two-part model in which the probability of a limit observation and the distribution of the non-limit observation are independently determined. In fact, in the Tobit model a positive coefficient $\beta$ indicates an increase both in the probability of introducing product innovation $P\left(y_{i}>0\right)$ and in the mean of the salesweighted measure of innovation $E\left(y_{i} \mid y_{i}>0\right)$. Let $I_{i}$ be an operator assuming value equal to 1 if firm $i$ has introduced product innovation and 0 otherwise. By taking account of $I_{i}$, the extended form of the log likelihood function takes the following form:

$$
\begin{gathered}
\operatorname{Ln} L=\sum_{i=1}^{N}\left\{\left(1-I_{i}\right) \ln \Phi\left(-X_{i} \beta_{1}\right)+I_{i}\left[\ln \Phi\left(X_{i} \beta_{1}\right)-\ln \Phi\left(X_{i} \beta_{2} / \sigma\right)+\right.\right. \\
\left.\left.-\frac{1}{2 \ln \left(2 \pi \sigma^{2}\right)}-\frac{1}{2 \sigma^{2}}\left(y_{i}-X_{i} \beta_{2}\right)^{2}\right]\right\}
\end{gathered}
$$

where $\Phi$ is the standard normal cumulative distribution function, $\beta_{1}$ is the parameter vector affecting the probability of a limit distribution and $\beta_{2}$ is the parameter vector of the truncated regression. Equation (4) collapses to the usual Tobit log likelihood function under the null hypothesis $H_{0}: \beta_{1}=\beta_{2} / \sigma$, where $\sigma$ is the standard deviation of the truncated regression. Traditionally, Cragg's test (Cragg, 1971) is the tool adopted for testing the Tobit model against the alternative two-part model. Cragg's test is based on a comparison between the likelihood ratios and is computed as follows:

$$
\lambda=-2\left[\log L_{T}-\left(\log L_{P}+\log L_{T R}\right)\right]
$$

where $L_{T}$ is the likelihood for the Tobit model, $L_{P}$ the likelihood for the Probit model, and $L_{T R}$ the likelihood for the truncated one; $\lambda$ has a distribution $\chi^{2}$ with $k+1$ degrees of freedom.

However, when sampling weights are used (as in this study), the "likelihood" obtained for MLEs may be misleading for statistical tests, since the weights mean the sample is no longer fully random.

\footnotetext{
${ }^{19}$ The error term in the truncated equation has a truncated normal distribution, i.e. a normal distribution that has been scaled upwards so that the distribution adds up to one over the restricted range.
} 
Therefore, Cragg's test based on a comparison between likelihood ratios may be biased ${ }^{20}$. A feasible alternative procedure is to run the probit and the truncated regressions separately, and then apply a non-linear Hausman-like test for testing cross-model hypotheses and, in particular, the restriction $H_{0}: \beta_{1}=\beta_{2} / \sigma$; in Section 6.1 an empirical application of this test is presented.

\subsection{Bivariate Probit}

The coexistence of two different targets of innovative activity - namely product and process innovation - and, more importantly, the possible complementarity/ substitutability between inputs and with respect to the two outputs, lead us to model the relationship between innovative inputs and outputs by simultaneously considering the process and product equations. Indeed, Barlet et al. (1998) underline the positive correlation between innovative outputs, and a similar finding applies to CIS 3 data: table 2 shows distribution of firms with respect to the introduction of product and process innovation. The data refers to two samples of firms: the first considers the 8,610 innovative and non-innovative firms, while the second group includes the 2,949 innovative firms selected through the procedure described in Section 3. As can be seen, firms are mostly located on the diagonal, the correlation between product and process innovation being positive and highly significant (0.54) for the 8,610 firms sample ${ }^{21}$.

Table 2. Distribution of firms according to product and process innovation

\begin{tabular}{|l|l|l|l|l|l|l|l|}
\hline \multicolumn{4}{|c|}{ 8610 firms } & \multicolumn{4}{c|}{ 2949 firms } \\
\hline & Process $^{22}$ & \multicolumn{4}{|l|}{ Process } \\
\hline Product & $\mathbf{0}$ & $\mathbf{1}$ & Total & Product & $\mathbf{0}$ & $\mathbf{1}$ & Total \\
\hline $\mathbf{0}$ & 5113 & 850 & $\mathbf{5 9 6 3}$ & $\mathbf{0}$ & 0 & 720 & $\mathbf{7 2 0}$ \\
\hline $\mathbf{1}$ & 850 & 1797 & $\mathbf{2 6 4 7}$ & $\mathbf{1}$ & 658 & 1571 & $\mathbf{2 2 2 9}$ \\
\hline Total & $\mathbf{5 9 6 3}$ & $\mathbf{2 6 4 7}$ & $\mathbf{8 6 1 0}$ & Total & $\mathbf{6 5 8}$ & $\mathbf{2 2 9 1}$ & $\mathbf{2 9 4 9}$ \\
\hline
\end{tabular}

The simultaneous consideration of the process and product equations requires a bivariate probit approach with correlated disturbances ${ }^{23}$ whose general specification is the following:

$$
\begin{cases}Y_{1 i}^{*}=\alpha_{1 i}+X_{1 i} \beta_{1}+\varepsilon_{1 i} & Y_{1 i}=1 \text { if } Y_{1 i}^{*}>0, Y_{1 i}=0 \text { otherwise } \\ Y_{2 i}^{*}=\alpha_{2 i}+X_{2 i} \beta_{2}+\varepsilon_{2 i} & Y_{2 i}=1 \text { if } Y_{2 i}^{*}>0, Y_{2 i}=0 \text { otherwise }\end{cases}
$$

where $\left\{\varepsilon_{1 i}, \varepsilon_{2 i}\right\} \sim \Phi_{2}(0,0,1,1, \rho)$.

\footnotetext{
${ }^{20}$ An alternative specification test has been proposed by Lin and Schmidt (1984). They derive a Lagrange Multiplier statistics based only on the Tobit model for testing the restriction $\beta_{1}=\beta_{2} / \sigma$. However, this test is also based on the likelihood function of the Tobit model and for this reason it suffers from the same limitations which affect the Cragg test.

${ }^{21}$ By definition, we do not have firms in the no product - no process cell for the 2,949 firms sample.

${ }^{22}$ Note that the value of 850 in two out of four cells is not a typing error.

${ }^{23}$ Estimating the two equations separately ensures consistency but is inefficient because it ignores the correlations between the residuals.
} 
The likelihood function for the bivariate probit is the following:

$$
L=\sum w_{i} \ln \Phi_{2}\left(q_{1 i}\left(X_{i} \beta\right)^{\beta}, q_{2 i}\left(z_{i} \gamma\right)^{\gamma}, \rho_{i}^{*}\right)
$$

where

$$
\left\{\begin{array}{l}
q_{1 i}=1 \text { if } Y_{1 i} \neq 0,-1 \text { otherwise } \\
q_{2 i}=1 \text { if } Y_{2 i} \neq 0,-1 \text { otherwise }
\end{array}\right.
$$

$w_{i}$ are optional weights and $\Phi_{2}$ is the bivariate normal cumulative distribution function which is used to estimate bivariate probit models:

$$
\int_{\varepsilon_{1}} \int_{\varepsilon_{2}} \Phi_{2}\left(\varepsilon_{1}, \varepsilon_{2}, \rho\right) d \varepsilon_{1} d \varepsilon_{2}
$$

The following likelihood ratio test verifies the hypothesis that the bivariate probit model fits the data better than two separate models:

$$
\lambda=-2\left[\left(\log L_{P R 1}+\log L_{P R 2}\right)-\log L_{B I P R}\right]
$$

where $L_{P R 1}$ is the likelihood for the first probit model (product innovation), $L_{P R 2}$ the likelihood for the second probit model (process innovation), and $L_{B I P R}$ the likelihood for the bivariate model ${ }^{24}$. This statistic $\lambda$ has a distribution $\chi_{1}^{2}$.

In the following econometric analysis, bivariate analysis turns out to be the correct procedure in modelling product and process innovation together: according to the first row of table A1 in the Appendix, correlated residuals between the two innovative outcomes are confirmed in four out of the five adopted specifications (with the only exception being the high-tech sectors ${ }^{25}$ ).

\footnotetext{
${ }^{24}$ The reasoning behind the test is that the joint likelihood is simply the product of the two separate marginal likelihoods; i.e. the joint log-likelihood is the sum of the two log likelihoods. Again, the likelihood ratio test here described should not be directly applied to weighted survey data; however, STATA computes an equivalent Wald test when sampling weights are used in the bivariate regression.

${ }^{25}$ Technically, this means that in the case of the high-tech sectors it would have been possible to run two independent probit regressions instead of one biprobit estimate. However, for reasons of comparability across this study, the following table 8 show the results from the bivariate regressions for both high-tech and low-tech sectors.
} 


\section{Descriptive Analysis}

Table 3 reports the normalised average values of the innovative inputs and outputs by sector and size. Analysis is focused on two sectors (low-tech and high-tech) and two size groups. Lowtech (LT) sectors include "supplier dominated" (traditional) sectors and "scale intensive" sectors in Pavitt's (1984) taxonomy; high-tech (HT) sectors are instead those resulting from the aggregation of "science based" and "specialised suppliers" sectors ${ }^{26}$. The dividing point between the two size groups is 50 employees; thus "S" (Small) refers to firms with less than 50 employees while "L" (Large) to firms with at least 50 employees.

Product innovation and TA expenditure differ greatly between size groups while sectors account more for the difference in $\mathrm{R} \& \mathrm{D}$ investment and process innovation. TA expenditure is strongly concentrated among small firms belonging to low-tech sectors. This is also the group of firms with the highest share of process innovation and with the lowest share of product innovation.

Table 3. Average values of R\&D shares, TA shares, product and process innovation by size and sector (2949 firms).

\begin{tabular}{|c|c|c|c|c|c|c|c|}
\hline R\&D & \multicolumn{2}{|c|}{ Size } & & TA & \multicolumn{2}{|c|}{ Size } & \\
\hline Sector & $\mathbf{S}$ & $\mathbf{L}$ & Total & Sector & $\mathbf{S}$ & $\mathbf{L}$ & Total \\
\hline LT & .0073 & .0085 & .0075 & LT & .0568 & .0254 & .0506 \\
\hline$\overline{\text { HT }}$ & .0251 & .0212 & .0241 & HT & .0257 & .0199 & .0242 \\
\hline Total & .0114 & .0124 & .0116 & Total & .0496 & .0237 & .0440 \\
\hline Prod. & \multicolumn{2}{|c|}{ Size } & & Proc. & \multicolumn{2}{|c|}{ Size } & \\
\hline Sector & $\mathbf{S}$ & $\mathbf{L}$ & Total & Sector & $\mathbf{S}$ & $\mathbf{L}$ & Total \\
\hline LT & .6241 & .7495 & .6489 & LT & .8465 & .8133 & .8399 \\
\hline HT & .8059 & .9083 & .8334 & HT & .6743 & .6714 & .6735 \\
\hline Total & .6659 & .7982 & .6944 & Total & .8069 & .7698 & .7988 \\
\hline \multicolumn{8}{|c|}{ Mean Comparison Test* } \\
\hline & Size & \multicolumn{2}{|c|}{ Sector } & & Size & \multicolumn{2}{|c|}{ Sector } \\
\hline $\mathbf{R} \& \mathbf{D}$ & $\begin{array}{c}.27 \\
{[.790]}\end{array}$ & \multicolumn{2}{|c|}{$\begin{array}{c}-15.05^{* *} \\
{[.000]}\end{array}$} & Prod. & $\begin{array}{l}-6.45^{* *} \\
{[.000]}\end{array}$ & \multicolumn{2}{|c|}{$\begin{array}{c}-10.86^{* *} \\
{[.000]}\end{array}$} \\
\hline TA & $\begin{array}{l}9.12^{* *} \\
{[.000]}\end{array}$ & \multicolumn{2}{|c|}{$\begin{array}{l}6.29^{* *} \\
{[.000]}\end{array}$} & Proc. & $\begin{array}{c}.71 \\
{[.481]}\end{array}$ & \multicolumn{2}{|c|}{$\begin{array}{l}8.75^{* *} \\
{[.000]}\end{array}$} \\
\hline \multicolumn{8}{|c|}{$\mathbf{P}$ values in brackets } \\
\hline \multicolumn{8}{|c|}{$\begin{array}{l}\text { * two-sample t test of } H_{o}: \mu_{1}=\mu_{2} \text { where the two groups are } \\
\text { defined by size ( } \mathbf{L} \text { and } \mathbf{S}) \text { and by sector (LT and HT). }\end{array}$} \\
\hline
\end{tabular}

Mean comparison tests confirm the importance of the sectoral divide for all the innovative inputs

\footnotetext{
${ }^{26}$ An official ISTAT conversion table permits the re-codifying of NACE sectors into Pavitt's taxonomy. In the following econometric analysis, Pavitt's quadripartite taxonomy is used when sectoral dummies are introduced as controlling variables, while in the sectoral estimates the HT/LT partition is adopted in order to maintain an acceptable number of observations in both the categories.
} 
and outputs, while size turns out to be significant in the TA and product innovation dimensions. Further proof of the difference in behaviour of these variables across sample groups is provided by table 4, where firms are distinguished by their innovative outcome.

Table 4. Average R\&D and TA expenditure by firms introducing product innovation only, process innovation only, and product and process innovation (2949 firms).

\begin{tabular}{|l|c|c|c|}
\hline & Product only & Process only & Product \& Process \\
\hline & (658 firms) & (720 firms) & (1571 firms) \\
\hline RD & $\mathbf{. 0 2 1}$ & $\mathbf{. 0 0 4}$ & $\mathbf{. 0 1 6}$ \\
\hline TA & $\mathbf{. 0 1 5}$ & $\mathbf{. 0 5 8}$ & $\mathbf{. 0 3 5}$ \\
\hline \multicolumn{4}{|c|}{ Correlation Matrix $\mathbf{( 2 9 4 9 ~ f i r m s ) ~}$} \\
\hline & \multicolumn{4}{|c|}{ Products } & Processes & RD \\
\hline RD & 0.18 & -0.11 & -0.05 \\
\hline TA & -0.16 & 0.15 & 0.18 \\
\hline Products & - & -0.30 & \\
\hline
\end{tabular}

$\mathrm{R} \& \mathrm{D}$ expenditure is five times higher for firms that have introduced only product innovation compared to those firms with only innovative processes. On the contrary, TA investment is four times higher for the latter compared to the former category of firms. Correlation coefficients between the two measures of inputs and outputs clearly indicate the occurrence of such a dichotomy between both inputs and outputs and between inputs with respect to outputs.

This divergence in the values of innovative inputs with respect to outcomes obtained by firms should be taken into account carefully, especially when econometric analysis focuses only on innovative firms. In fact, while each input positively contributes to the change of a firm's status from "non-innovative" to "innovative", a different context arises when all the analysed firms belong to the "innovative" status. In particular, as can be seen from tables 3 and 4 , different symmetric features of the innovative activity can be singled out when firms introduce either product or process innovation. This divergence opens the way to the revealed negative correlations between an innovative input peculiar to one group and the innovative output distinctive of the other group (see the second panel of table 4 and the next section).

To sum up, firms (especially small firms) in low-tech sectors appear to be characterised by a dominant role of TA on the input side and of process innovation with regard to their innovative output. Symmetrically, firms (especially large firms) in high-tech sectors seem devoted to R\&D-intensive innovation activity, mainly targeting product innovation. These preliminary descriptive statistics are not in contrast with the hypotheses proposed in Section 2.

\section{Empirical Results}

\subsection{Tobit vs Two Part Model}

In order to test whether a Tobit or a two-part model is more accurate when estimating the effects of inputs on product innovation and innovative sales, we have run both a traditional Cragg test 
using unweighted ISTAT data and the non-linear Hausman-like test proposed in Section 4.2, using the weighted data actually adopted in the econometric exercises ${ }^{27}$. As can be seen from table 5 , both tests give consistent results. In particular, the Tobit model is rejected in all the five samples of firms, in favour of a two-equation model that allows regressors to have a different impact on the introduction of product innovation and on the sales-weighted measure of innovativeness.

\section{Table 5. Tobit vs Two Part Model}

\begin{tabular}{|c|c|l|}
\hline & Unweighted Data & Weighted Data \\
\hline & LR based Cragg Test & Non Linear Test \\
\hline Log L. & Value of Test & Value of Test \\
\hline All & $180.94^{* *}[.000]$ & $73.43^{* *}[.000]$ \\
\hline S & $79.96^{* *}[.000]$ & $38.91^{* *}[.000]$ \\
\hline L & $94.13^{* *}[.000]$ & $27.47^{* *}[.003]$ \\
\hline LT & $99.99^{* *}[.000]$ & $49.17^{* *}[.000]$ \\
\hline HT & $67.95^{* *}[.000]$ & $36.65^{* *}[.000]$ \\
\hline P values in brackets \\
\hline * significant at 5\%; ** significant at 1\% \\
\hline
\end{tabular}

\subsection{Aggregate Estimates}

Aggregate bivariate probit estimates (table 6) show a positive impact of $R \& D$ investment on the probability of introducing product innovation, while the TA coefficient turns out to be significantly positive with respect to process innovation. The negative impacts of R\&D and TA on, respectively, process and product innovation, confirm the existence of substitutability between inputs among innovative firms. This result appears consistent with the descriptive evidence in table 4 and the revealed symmetric roles played by the two innovative inputs, as discussed in Section 5 above. In other words, the negative impacts of $\mathrm{R} \& \mathrm{D}$ and TA on process and product innovation respectively have to be interpreted more as statistical artefacts rather than explanatory relationships. Reminding the reader of the fact that our sample is made up only of innovative firms, the dichotomy discussed in Section 5 gives rise to such artefacts as the arithmetical outcome of the maximum likelihood estimations used in the biprobit analysis. In fact, turning our attention to the truncated analysis from the two-part model where the dependent variable is the sales ratio of innovative products, both the R\&D and TA coefficients are positive, although only the former turns out to be statistically significant ${ }^{28}$.

Cooperation agreements based on market interaction and firm's size are significant in the product equation only. Notice that the negative coefficient of a firm's size in the truncated estimate also indicates a compositional arithmetical effect: smaller firms (with lower sales) have a higher share of turnover related to innovative products successfully introduced onto the market ${ }^{29}$. Belonging to an industrial group is significant in the first and third estimates. Finally, regional dummies are jointly

\footnotetext{
${ }^{27}$ Unweighted and weighted estimates used to compute the Cragg test and the Hausman-like test are available on request.

${ }^{28} \mathrm{R} \& \mathrm{D}$ impact on the innovative sales ratio is also found to be significant in Crepon et al. (1998).

${ }^{29}$ Brouwer and Kleinknecht (1996) also report a negative impact of firm size on the share of innovative products in total sales by using CIS data for the Netherlands.
} 
significant only in the bivariate specification, while sectoral dummies are jointly significant for all the estimates ${ }^{30}$.

These results confirm the symmetric role of $\mathrm{R} \& \mathrm{D}$ and $\mathrm{TA}$ in fostering product and process innovation respectively, although both increase innovation intensity. Moreover, the more complex product innovation seems to be facilitated by cooperation agreements and belonging to a group, while these factors do not seem crucial in the simpler and more routinised process innovation. Finally, the Schumpeterian hypothesis - supporting the innovative advantage of larger firms - is confirmed only for product innovation, and not for process innovation where, in fact, small firms appear particularly active (see table 3 ).

Table 6. Aggregate Estimates. 2949 firms.

\begin{tabular}{|c|c|c|c|}
\hline & \multicolumn{2}{|c|}{ BIPROBIT } & TRUNCATED \\
\hline & Product & Process & Turninn \\
\hline R\&D & $\begin{array}{l}11.000^{*} \\
{[5.057}\end{array}$ & $\begin{array}{l}-4.997^{* *} \\
{[1.435]}\end{array}$ & $\begin{array}{l}1.185^{* *} \\
{[0.330]}\end{array}$ \\
\hline TA & $\begin{array}{l}-2.586^{* *} \\
{[0.582]}\end{array}$ & $\begin{array}{l}5.195^{* *} \\
{[1.744]}\end{array}$ & $\begin{array}{c}0.292 \\
{[0.199]}\end{array}$ \\
\hline cores & $\begin{array}{c}0.354 \\
{[0.183]}\end{array}$ & $\begin{array}{c}0.196 \\
{[0.140]}\end{array}$ & $\begin{array}{c}0.080 \\
{[0.050]}\end{array}$ \\
\hline comkt & $\begin{array}{c}0.598^{* *} \\
{[0.194]}\end{array}$ & $\begin{array}{c}0.227 \\
{[0.125]}\end{array}$ & $\begin{array}{c}0.025 \\
{[0.055]}\end{array}$ \\
\hline gp & $\begin{array}{c}0.308^{* *} \\
{[0.106]}\end{array}$ & $\begin{array}{l}-0.083 \\
{[0.099]}\end{array}$ & $\begin{array}{c}0.121^{*} \\
{[0.048]}\end{array}$ \\
\hline logsize & $\begin{array}{c}0.102^{*} \\
{[0.045]}\end{array}$ & $\begin{array}{l}-0.013 \\
{[0.038]}\end{array}$ & $\begin{array}{l}-0.068^{* *} \\
{[0.018]}\end{array}$ \\
\hline rdbased & $\begin{array}{c}0.590^{* *} \\
{[0.142]}\end{array}$ & $\begin{array}{l}-0.487^{* *} \\
{[0.114]}\end{array}$ & $\begin{array}{l}0.117^{* *} \\
{[0.040]}\end{array}$ \\
\hline spsuppl & $\begin{array}{c}0.379^{* *} \\
{[0.131]}\end{array}$ & $\begin{array}{l}-0.550^{* *} \\
{[0.116]}\end{array}$ & $\begin{array}{c}0.129^{* *} \\
{[0.041]}\end{array}$ \\
\hline trad & $\begin{array}{l}-0.004 \\
{[0.101]}\end{array}$ & $\begin{array}{l}-0.171 \\
{[0.102]}\end{array}$ & $\begin{array}{c}0.049 \\
{[0.043]}\end{array}$ \\
\hline nwest & $\begin{array}{l}-0.303^{*} \\
{[0.146]}\end{array}$ & $\begin{array}{c}0.277^{*} \\
{[0.130]}\end{array}$ & \\
\hline neast & $\begin{array}{l}-0.277 \\
{[0.144]}\end{array}$ & $\begin{array}{c}0.113 \\
{[0.131]}\end{array}$ & \\
\hline south & $\begin{array}{c}0.280 \\
{[0.159]}\end{array}$ & $\begin{array}{l}-0.091 \\
{[0.159]}\end{array}$ & \\
\hline constant & $\begin{array}{c}0.227 \\
{[0.205]}\end{array}$ & $\begin{array}{c}0.867^{* *} \\
{[0.191]}\end{array}$ & $\begin{array}{c}0.371^{* *} \\
{[0.070]}\end{array}$ \\
\hline Obs. & 2949 & 2949 & 2229 \\
\hline $\begin{array}{l}\text { Robust } \mathrm{s} \\
*^{*} \text { signific }\end{array}$ & $\begin{array}{l}\text { ndard er } \\
\text { t at } 5 \% \text {; }\end{array}$ & $\begin{array}{l}\text { * }{ }^{*} \text { signif } \\
\text { sin bl }\end{array}$ & ets at $1 \%$ \\
\hline
\end{tabular}

\footnotetext{
${ }^{30}$ Regional and sectoral dummies are not reported if they are jointly not significant (see tables A1 and A2 in the Appendix). The default dummies are the supplier-dominated firms in the sectoral control and Central Italy in the regional control.
} 


\subsection{Estimates by firm's size}

Several differences arise in the input-output relationship with respect to firm's size (table 7). R\&D and TA have effects on, respectively, product and process innovation, following the patterns obtained in the aggregate estimates. However, the marginal effect of $\mathrm{R} \& \mathrm{D}$ on product innovation (see table A3) is higher and more significant for large firms ${ }^{31}$. Symmetrically, the TA coefficient and marginal effect on process innovation are large and statistically significant only for small firms (see tables 7 and A3). These outcomes are consistent with the hypotheses proposed in Section 2 and allow us to better qualify the results obtained in the aggregate estimates. First, although R\&D expenditures are good predictors of innovative intensity for both large and small firms (see the results from the truncated estimates in table 7), they appear particularly important in fostering product innovation, especially within large corporations. Conversely, TA is strongly linked to process innovation and this relationship is particularly obvious in the small firms.

Moreover, table 7 reveals that product innovation requires small firms to arrange cooperation agreements for technological purposes both with customers, suppliers and competitors and with research-based institutions. This appears to be a way to compensate possible weaknesses as far as endogenous resources and capabilities are concerned (see the discussion in Section 3.3). The stronger dependence of small firms on the economic and technological environment to which they belong is further reinforced by the finding that regional dummies are jointly significant only for those firms (table A1).

Industrial group is the only dummy that positively affects product innovation for both large and small firms, although its coefficient turns out to be higher for the latter (and positive and significant only for small firms in the truncated equation). These further outcomes confirm the idea that it is the weaker small firms that need more external aid in sustaining their innovative activity.

Table 7. Estimates by firm's size

\begin{tabular}{|l|l|l|l|l|l|l|}
\hline & \multicolumn{4}{|c|}{ BIPROBIT } & \multicolumn{2}{c|}{ TRUNCATED } \\
\hline & Prod L & Proc L & Prod S & Proc S & Turninn L & Turninn S \\
\hline R\&D & $17.643^{* *}$ & -2.261 & $10.691^{*}$ & $-6.014^{* *}$ & $1.168^{* *}$ & $1.191^{* *}$ \\
& {$[6.552]$} & {$[1.471]$} & {$[5.348]$} & {$[1.780]$} & {$[0.415]$} & {$[0.405]$} \\
\hline TA & $-2.705^{* *}$ & 2.389 & $-2.593^{* *}$ & $6.423^{* *}$ & 0.164 & 0.381 \\
& {$[1.006]$} & {$[1.704]$} & {$[0.628]$} & {$[2.335]$} & {$[0.337]$} & {$[0.224]$} \\
\hline cores & 0.199 & 0.028 & $0.801^{*}$ & 0.305 & 0.070 & 0.051 \\
& {$[0.159]$} & {$[0.149]$} & {$[0.333]$} & {$[0.225]$} & {$[0.072]$} & {$[0.067]$} \\
\hline comkt & 0.159 & 0.231 & $0.911^{* *}$ & 0.261 & 0.028 & 0.033 \\
& {$[0.152]$} & {$[0.148]$} & {$[0.293]$} & {$[0.198]$} & {$[0.074]$} & {$[0.073]$} \\
\hline
\end{tabular}

\footnotetext{
${ }^{31}$ Santarelli and Sterlacchini (1990) provide evidence that systematic R\&D carried out by large firms is more effective than R\&D undertaken by small firms for the introduction of product innovation.
} 


\begin{tabular}{|l|c|c|c|c|c|c|}
\hline gp & $0.217^{*}$ & $-0.235^{*}$ & $0.438^{*}$ & 0.091 & -0.039 & $0.173^{*}$ \\
& {$[0.103]$} & {$[0.100]$} & {$[0.174]$} & {$[0.167]$} & {$[0.038]$} & {$[0.067]$} \\
\hline rdbased & 0.164 & $-0.307^{*}$ & $0.737^{* *}$ & $-0.545^{* *}$ & 0.065 & $0.126^{*}$ \\
& {$[0.176]$} & {$[0.143]$} & {$[0.175]$} & {$[0.147]$} & {$[0.051]$} & {$[0.053]$} \\
\hline spsuppl & $0.654^{* *}$ & $-0.554^{* *}$ & $0.323^{*}$ & $-0.513^{* *}$ & 0.041 & $0.154^{* *}$ \\
& {$[0.162]$} & {$[0.133]$} & {$[0.159]$} & {$[0.148]$} & {$[0.049]$} & {$[0.054]$} \\
\hline trad & 0.025 & -0.121 & -0.007 & -0.194 & -0.031 & 0.069 \\
& {$[0.121]$} & {$[0.119]$} & {$[0.121]$} & {$[0.129]$} & {$[0.052]$} & {$[0.053]$} \\
\hline nwest & -0.101 & 0.245 & $-0.350^{*}$ & 0.292 & & \\
& {$[0.162]$} & {$[0.136]$} & {$[0.170]$} & {$[0.161]$} & & \\
\hline neast & -0.195 & 0.108 & -0.284 & 0.105 & & \\
& {$[0.158]$} & {$[0.138]$} & {$[0.165]$} & {$[0.159]$} & & \\
\hline south & -0.014 & -0.127 & 0.341 & -0.039 & & \\
& {$[0.195]$} & {$[0.182]$} & {$[0.186]$} & {$[0.188]$} & & $0.149^{* *}$ \\
\hline constant & $0.609^{* *}$ & $0.857^{* *}$ & $0.524^{* *}$ & $0.803^{* *}$ & $0.167^{* *}$ & {$[0.044]$} \\
\hline
\end{tabular}

\subsection{Estimates by sectors}

In general terms, R\&D and TA coefficients behave in the usual way with respect to product innovation, process innovation and innovative intensity (table 8). However, R\&D coefficient and marginal effect on product innovation in the HT sectors are lower than the corresponding values in LT sectors (see tables 8 and A3). These outcomes suggest the existence of decreasing returns on R\&D activity, given that in LT sectors the average value of $\mathrm{R} \& \mathrm{D}$ expenditure is roughly two thirds lower than in the high-tech sectors (see table 3). Similar results are obtained by Mairesse and Mohen (2004).

TA significantly affects process innovation only in the low-tech sectors. This additional outcome allows us to conclude that TA is a crucial input in the KPF of process innovation and this is particularly pertinent to small firms active in traditional sectors.

Belonging to an industrial group and cooperation agreements with market-based partners, which foster product innovation, as emerged in the previous section, are also significant only in the LT sectors, supporting the proposed hypothesis that low-technology firms need more external aid than their high-tech counterparts (see Section 3.3). Bearing the Italian industrial structure in mind, one might guess that the former are mainly small firms, consistently with the results which emerged in the previous section. In fact, in table 8 the Schumpeterian hypothesis turns out to be confirmed only in the high-tech sectors, suggesting the need for a larger size as a pre-requisite for product innovation in the science-based and specialised supplier sectors but not in the traditional ones. To sum up, product innovation is not precluded to small firms in traditional sectors, provided they group together in business groups or/and in cooperation agreements. 
Table 8. Estimates by Sectors

\begin{tabular}{|c|c|c|c|c|c|c|}
\hline & \multicolumn{4}{|c|}{ BIPROBIT } & \multicolumn{2}{|c|}{ TRUNCATED } \\
\hline & Prod HT & Proc HT & Prod LT & Proc LT & Turninn HT & Turninn LT \\
\hline $\mathbf{R} \& \mathbf{D}$ & $\begin{array}{l}9.512^{*} \\
{[4.729]}\end{array}$ & $\begin{array}{l}-5.043^{* *} \\
{[1.588]}\end{array}$ & $\begin{array}{l}18.094^{* *} \\
{[4.712]}\end{array}$ & $\begin{array}{l}-5.027^{*} \\
{[2.398]}\end{array}$ & $\begin{array}{l}0.926^{* *} \\
{[0.349]}\end{array}$ & $\begin{array}{c}1.409^{*} \\
{[0.604]}\end{array}$ \\
\hline TA & $\begin{array}{l}-8.367^{* *} \\
{[2.123]}\end{array}$ & $\begin{array}{c}6.175 \\
{[3.180]}\end{array}$ & $\begin{array}{l}-1.997^{* *} \\
{[0.516]}\end{array}$ & $\begin{array}{l}5.198^{* *} \\
{[2.002]}\end{array}$ & $\begin{array}{l}-0.050 \\
{[0.360]}\end{array}$ & $\begin{array}{c}0.395 \\
{[0.224]}\end{array}$ \\
\hline cores & $\begin{array}{c}0.161 \\
{[0.275]}\end{array}$ & $\begin{array}{c}0.442^{*} \\
{[0.184]}\end{array}$ & $\begin{array}{c}0.394 \\
{[0.233]}\end{array}$ & $\begin{array}{c}0.026 \\
{[0.200]}\end{array}$ & $\begin{array}{l}0.094 \\
{[0.059]}\end{array}$ & $\begin{array}{c}0.056 \\
{[0.073]}\end{array}$ \\
\hline comkt & $\begin{array}{c}0.213 \\
{[0.286]}\end{array}$ & $\begin{array}{c}0.150 \\
{[0.178]}\end{array}$ & $\begin{array}{l}0.685^{* *} \\
{[0.220]}\end{array}$ & $\begin{array}{c}0.332 \\
{[0.173]}\end{array}$ & $\begin{array}{c}0.074 \\
{[0.050]}\end{array}$ & $\begin{array}{l}-0.012 \\
{[0.086]}\end{array}$ \\
\hline gp & $\begin{array}{c}0.324 \\
{[0.205]}\end{array}$ & $\begin{array}{l}-0.172 \\
{[0.149]}\end{array}$ & $\begin{array}{c}0.320^{*} \\
{[0.125]}\end{array}$ & $\begin{array}{l}-0.030 \\
{[0.126]}\end{array}$ & $\begin{array}{c}0.063 \\
{[0.042]}\end{array}$ & $\begin{array}{c}0.159^{*} \\
{[0.072]}\end{array}$ \\
\hline logsize & $\begin{array}{c}0.232^{* *} \\
{[0.086]}\end{array}$ & $\begin{array}{l}-0.006 \\
{[0.061]}\end{array}$ & $\begin{array}{c}0.060 \\
{[0.050]}\end{array}$ & $\begin{array}{l}-0.020 \\
{[0.049]}\end{array}$ & $\begin{array}{l}-0.066^{* *} \\
{[0.017]}\end{array}$ & $\begin{array}{l}-0.068^{*} \\
{[0.027]}\end{array}$ \\
\hline nwest & $\begin{array}{l}-0.084 \\
{[0.230]}\end{array}$ & $\begin{array}{c}0.120 \\
{[0.172]}\end{array}$ & $\begin{array}{l}-0.329^{*} \\
{[0.164]}\end{array}$ & $\begin{array}{l}0.364^{*} \\
{[0.161]}\end{array}$ & & \\
\hline neast & $\begin{array}{l}-0.116 \\
{[0.231]}\end{array}$ & $\begin{array}{l}-0.012 \\
{[0.172]}\end{array}$ & $\begin{array}{l}-0.300 \\
{[0.161]}\end{array}$ & $\begin{array}{c}0.162 \\
{[0.159]}\end{array}$ & & \\
\hline south & $\begin{array}{c}0.304 \\
{[0.294]}\end{array}$ & $\begin{array}{l}-0.207 \\
{[0.294]}\end{array}$ & $\begin{array}{c}0.294 \\
{[0.173]}\end{array}$ & $\begin{array}{l}-0.052 \\
{[0.179]}\end{array}$ & & \\
\hline const. & $\begin{array}{c}0.287 \\
{[0.340]}\end{array}$ & $\begin{array}{c}0.411 \\
{[0.263]}\end{array}$ & $\begin{array}{c}0.308 \\
{[0.234]}\end{array}$ & $\begin{array}{l}0.740^{* *} \\
{[0.240]}\end{array}$ & $\begin{array}{l}0.545^{* *} \\
{[0.071]}\end{array}$ & $\begin{array}{c}0.359^{* *} \\
{[0.096]}\end{array}$ \\
\hline Obs. & 913 & 913 & 2036 & 2036 & 805 & 1424 \\
\hline
\end{tabular}

\section{Concluding Remarks}

This paper has discussed the determinants of three alternative measures of innovative output by looking both at firms' own formal R\&D activities and at the acquisition of external technology in its embodied and disembodied components. These input-output relationships have also been discussed by distinguishing between small and large firms and those belonging to low-tech and high-tech sectors.

Results show that R\&D is strictly linked to product innovation, while TA is crucial in fostering process innovation; however, both inputs increase a firm's innovative intensity.

Firm's size and sector of activity turn out to be important discriminating factors for the description of the innovative process at the firm level. In particular, our estimates indicate that small firms and firms in the low-tech sectors rely more on external technology: in these firms innovation is mainly achieved through investment in TA and by participating in cooperation agreements and business groups. In contrast, large firms and firms in high-tech sectors rely heavily on their own $\mathrm{R} \& \mathrm{D}$ innovative effort, although some evidence of decreasing returns emerges as far as the sectoral dimension is concerned. 


\section{Appendix: Tests and Marginal Effects in the Regressions}

Table A1. Tests - Bivariate Probit Regressions

\begin{tabular}{|l|r|r|r|r|c|}
\hline \multicolumn{1}{|c|}{ Wald Tests } & All & L & S & HT & LT \\
\hline Absence of residuals & $475.06^{* *}$ & $222.71^{* *}$ & $397.96^{* *}$ & 2.23 & $430.71^{* *}$ \\
correlation $(\rho=0) \chi_{1}^{2}$ & {$[.000]$} & {$[.000]$} & {$[.000]$} & {$[.136]$} & {$[.000]$} \\
\hline Joint significance of & $47.63^{* *}$ & $30.49^{* *}$ & $34.59^{* *}$ & & \\
sectoral dummies $\left(\chi_{6}^{2}\right)$ & {$[.000]$} & {$[.000]$} & {$[.000]$} & & \\
\hline Joint significance of & $29.36^{* *}$ & 8.41 & $25.07^{* *}$ & 3.86 & $29.22^{* *}$ \\
regional dummies $\left(\chi_{6}^{2}\right)$ & {$[.000]$} & {$[.210]$} & {$[.000]$} & {$[.700]$} & {$[.000]$} \\
\hline P values in brackets & \begin{tabular}{l}
$\mid l$ \\
\hline * significant at 5\%; ** significant at 1\%
\end{tabular} \\
\hline Observations with the dependent variable equal to 1 \\
\hline product =1 & $75.6 \%$ & $80.5 \%$ & $70.4 \%$ & $88.2 \%$ & $69.9 \%$ \\
\hline process =1 & $77.7 \%$ & $77.2 \%$ & $78.2 \%$ & $67.8 \%$ & $82.1 \%$ \\
\hline prod. and proc. $=\mathbf{1}$ & $53.3 \%$ & $57.7 \%$ & $48.6 \%$ & $56.0 \%$ & $52.1 \%$ \\
\hline
\end{tabular}

Table A2. Tests - Truncated regressions

\begin{tabular}{|l|c|l|l|l|l|}
\hline Wald Test & Full Sample & \multicolumn{1}{|c|}{ L } & \multicolumn{1}{|c|}{ S } & HT & LT \\
\hline Joint significance of & $12.98^{*}$ & 3.93 & $9.54^{*}$ & & \\
sectoral dummies $\left(\chi_{3}^{2}\right)$ & {$[.005]$} & {$[.269]$} & {$[.023]$} & & \\
\hline Joint significance of & 2.20 & 2.44 & 1.58 & 0.68 & 3.59 \\
regional dummies $\left(\chi_{3}^{2}\right)$ & {$[.531]$} & {$[.485]$} & {$[.664]$} & {$[.879]$} & {$[.309]$} \\
\hline P values in brackets \\
\hline * significant at 5\%; ** significant at 1\% \\
\hline
\end{tabular}


Table A3. Marginal Effects

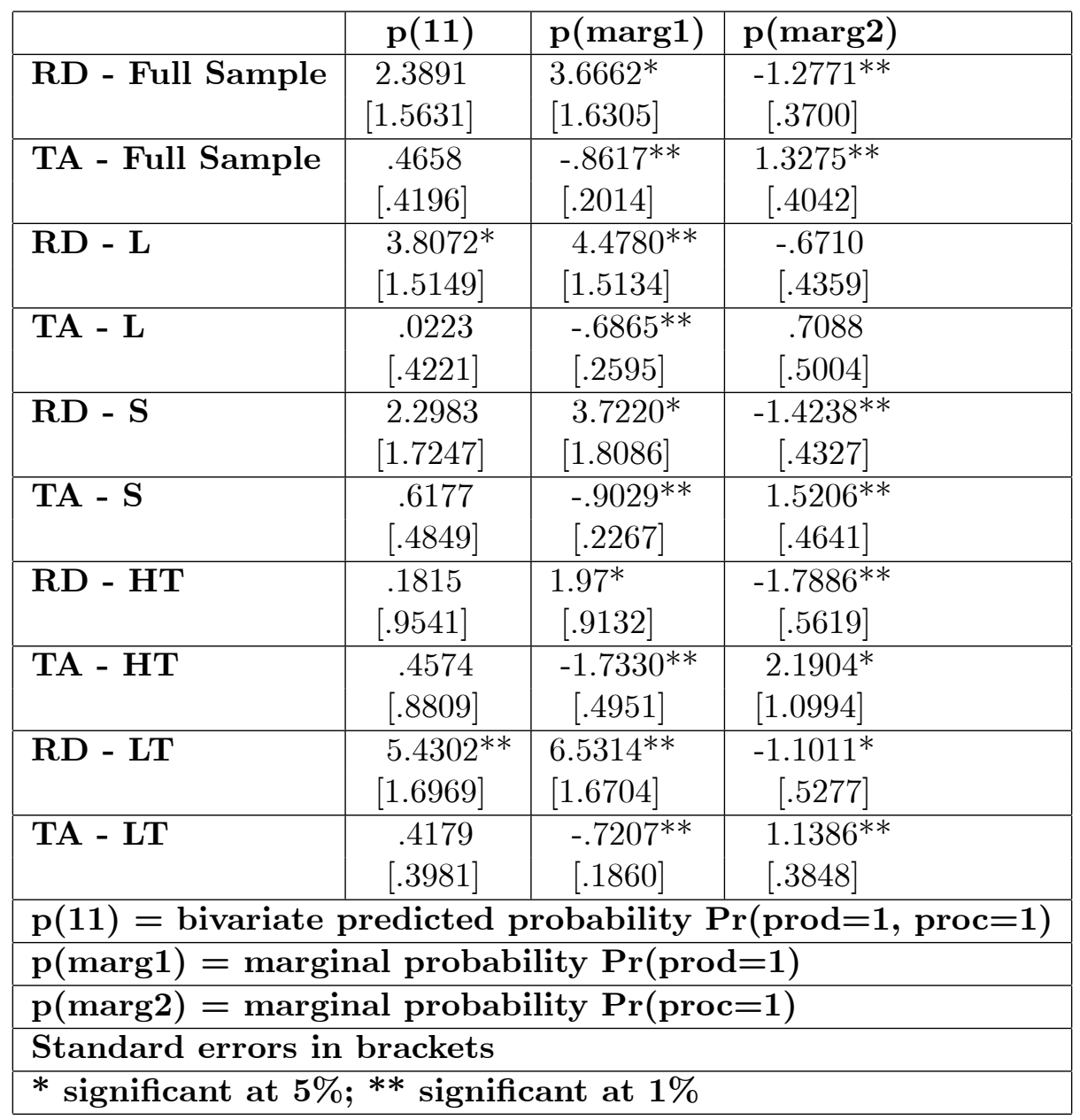




\section{References}

Acs, Zoltan J., \& Audretsch, David B. 1988. Innovation in Large and Small Firms: An Empirical Analysis. The American Economic Review, Vol. 78(No. 4), pp. 678-690.

Acs, Zoltan J., \& Audretsch, David B. 1990. Innovation and Small Firms. Cambridge (Mass.): MIT Press.

Acs, Zoltan J., Audretsch, David B., \& Feldman, Maryann P. 1991. Real Effects of Academic Research: Comment. The American Economic Review, Vol. 82(No. 1), pp. 363367.

Acs, Zoltan J., Audretsch, David B., \& Feldman, Maryann P. 1994. R\&D Spillovers and Recipient Firm Size. The Review of Economics and Statistics, Vol. 4(No. 2), pp. 336-340.

Archibugi, Daniele, \& Pianta, Mario. 1992. The Technological Specialization of Advanced Countries: A Report to the EEC on International Science and Technology Activities. Boston: Kluwer Academic Publisher.

Barlet, Corinne, Duguet, Emmanuel, Enchoua, David, \& Pradel, Jacqueline. 1998. The Commercial Success of Innovations: an Econometric Analysis at the Firm Level in French Manufacturing. Annales d'Economie et de Statistique, No. 49/50, pp. 457-478. Published also in D. Encaoua et al. (eds.), The Economics and Econometrics of Innovation, Boston: Kluwer Academic Publishers, 2000, pp. 435-456.

Bernstein, Jeffrey I., \& Nadiri, M. Ishaq. 1989. Research and Development and Intraindustry Spillovers: An Empirical Application of Dynamic Duality. The Review of Economic Studies, Vol. 56(No. 2), pp. 249-267.

Breschi, Stefano, F.Malerba, \& L.Orsenigo. 2000. Technological Regimes and Schumpeterian Patterns of Innovation. The Economic Journal, Vol. 110(No. 463), pp. 388-410.

Brouwer, Erik, \& Kleinknecht, Alfred. 1996. Firm Size, Small Business Presence and Sales of Innovative Products: A Micro-econometric Analysis. Small Business Economics, Vol. 8, pp. 189-201.

Cassiman, Bruno, \& Veugelers, Reinhilde. 2002. R\&D Cooperation and Spillovers: Some Empirical Evidence from Belgium. The American Economic Review, Vol. 92(No. 4), pp.11691184.

Cohen, Wesley M., \& Klepper, Steven. 1996. A Reprise of Size and R\&D. The Economic Journal, Vol. 106(No. 437), pp. 925-951.

Cohen, Wesley M., \& Levinthal, Daniel A. 1989. Innovation and Learning: the two Faces of R\&D. The Economic Journal, Vol. 99(No. 397), pp. 569-596.

Cragg, John G. 1971. Some Statistical Models for Limited Dependent Variables with Application to the Demand for Durable Goods. Econometrica, Vol. 39(No. 5), pp. 829-844.

Crepon, Bruno, Duguet, Emmanuel, \& Mairesse, Jacques. 1998. Research, Innovation and Productivity: an Econometric Analysis at the Firm Level. Economics of Innovation and New Technology, Vol. 7(No. 3), pp. 115-156. 
Deaton, Angus. 1997. The Analysis of Household Surveys. A Microeconometric Approach to Development Policy. The Johns Hopkins University Press.

Dosi, Giovanni. 1988. Sources, Procedures, and Microeconomic Effects of Innovation. Journal of Economic Literature, Vol. 26(No. 3), pp. 1120-1171.

Feldman, Maryann P. 1994. Knowledge Complementarity and Innovation. Small Business Economics, Vol. 6, pp. 363-372.

Freeman, Christofer. 1982. The Economics of Industrial Innovation. 2nd edn. Frances Pinter.

Freeman, Christofer, \& Soete, Luc. 1987. Technical Change and Full Employment. Oxford: Basil Blackwell.

Freeman, Christofer, Clark, John, \& Soete, Luc. 1982. Unemployment and Technical Innovation. London Pinter.

Fritsch, Michael, \& Franke, Grit. 2004. Innovation, Regional Knowledge Spillovers and R\&D Cooperation. Research Policy, Vol. 33(Issue 2), pp. 245-255.

Gilbert, R., \& Newbery, D. 1982. Preemptive Patenting and the Persistence of Monopoly. The American Economic Review, Vol. 72(No. 3), pp. 514-526.

Griffith, Rachel, Redding, Stephen, \& Reenen, John Van. 2003. R\&D and Absorptive Capacity: Theory and Empirical Evidence. Scandinavian Journal of Economics, Vol. 105(No. 1), pp. 99-118.

Griliches, Zvi. 1979. Issues in Assessing the Contribution of Research and Development to Productivity Growth. The Bell Journal of Economics, Vol. 10(No. 1), pp. 92-116.

Griliches, Zvi. 1990. Patent Statistics as Economic Indicators: A Survey. Journal of Economic Literature, Vol. 28(No. 4), pp. 1661-1707.

Griliches, Zvi. 1995. RESD and Productivity: Econometric Results and Measurement Issues. In Stoneman P. (ed.), "Handbook of the Economics of Innovation and Technological Change", Blackwell Publishers Ltd., pp. 52-89.

Hall, Bronwyn H. 1996. The Private and Social Returns to Research and Development. In Smith B.L.R. and Barfield C.E. (eds.), "Technology, R\&D, and the Economy", Washington, DC: Brookings Institution and American Enterprise Institute, pp. 140-183.

Hall, Bronwyn H. 2000. Innovation and Market Value. In Barrell R., Mason G. and O'Mahoney M. (eds.), "Productivity, Innovation and Economic Performance", Cambridge: Cambridge University Press.

Hall, Bronwyn H., \& Mairesse, Jacques. 1995. Exploring the Relationship between R\&D and Productivity in French Manufacturing Firms. Journal of Econometrics, Vol. 65(Issue 1), pp. $263-293$.

Hall, Bronwyn H., Jaffe, Adam, \& Trajtenberg, Manuel. 2004. Market Value and Patent Citations. Rand Journal of Economics, Vol. 36(No. 1), pp. 16-38.

Harhoff, Dietmar, Scherer, Frederic M., \& Vopel, Katrin. 2003. Citations, Family Size, Opposition, and the Value of Patent Rights. Research Policy, Vol. 32(Issue 8), pp. 1343-1364. 
ISTAT. 2004. Statistiche sull' Innovazione delle Imprese. Settore Industria. Anni 1998-2000. Rome.

Jaffe, Adam B. 1989. Real Effects of Academic Research. The American Economic Review, Vol. 79(No. 5), pp. 957-970.

Kline, R., \& Rosenberg, N. 1986. An overview of Innovation. In Landau R. and Rosenberg N. (eds.), "The Positive Sum Strategy", Washington DC: National Academy Press.

Levin, Richard C., Klevorick, Alvin K., Nelson, Richard R., Winter, Sidney G., Gilbert, Richard, \& Griliches, Zvi. 1988. Appropriating the Returns from Industrial Research and Development. Brookings Papers on Economic Activity, Vol. 1987(No. 3), pp. $783-831$.

Lin, Tsai-Fen, \& Schmidt, Peter. 1984. A Test of the Tobit Specification Against an Alternative Suggested by Cragg. The Review of Economics and Statistics, Vol. 66(No. 1), pp. 174-177.

Loof, Hans, \& Heshmati, Almas. 2001. On the Relationship between Innovation and Performance: a Sensitivity Analysis. Tech. rept. No. 446. ECIS - Eindhoven Centre for innovation Studies.

Loof, Hans, \& Heshmati, Almas. 2002. Knowledge Capital and Performance Heterogeneity: A Firm-Level Innovation Study. International Journal of Production Economics, Vol. 76(Issue 1), pp. 61-85.

Mairesse, Jacques, \& Mohnen, Pierre. 2002. Accounting for Innovation and Measuring Innovativeness: An Illustrative Framework and an Application. The American Economic Review, Papers and Proceedings, Vol. 92(No. 2), pp. 226-230.

Mairesse, Jacques, \& Mohnen, Pierre. 2004. The Importance of R\&D for Innovation: A Reassessment Using French Survey Data. The Journal of Technology Transfer, Vol. 30(No. 1-2), pp. 183-197.

Malerba, Franco. 2002. Sectoral Systems of Innovation and Production. Research Policy, Vol. 31(Issue 2), pp. 247-264.

Malerba, Franco, \& Orsenigo, Luigi. 1996. Schumpeterian Patterns of Innovation. Cambridge Journal of Economics, Vol. 19(Issue 1), pp. 47-65.

Nelson, Richard R., \& Winter, Sidney. 1982. An Evolutionary Theory of Economic Change. Cambridge (Mass.): Harvard University Press.

OECD. 1997. Oslo Manual: The Measurement Of Scientific and Technological Activities. Proposed Guideline for collecting and Interpreting Technological Innovation Data.

Parisi, Maria laura, Schiantarelli, Fabio, \& Sembenelli, Alessandro. 2005. Productivity, Innovation and R\&D: Micro Evidence for Italy. European Economic Review, forthcoming.

Patel, Pari, \& Pavitt, Keith. 1995. Patterns of Technological Activity: their Measurement and Interpretation. In Stoneman P. (ed.), "Handbook of the Economics of Innovation and Technological Change", Blackwell Publishers Ltd., pp. 14-51.

Pavitt, Keith. 1984. Sectoral Patterns of Technical Change: towards a Taxonomy and a Theory. Research Policy, Vol. 13(Issue 6), pp. 343-373. 
Piga, Claudio A., \& Vivarelli, Marco. 2004. Internal and External R\&D: A Sample Selection Approach. Oxford Bulletin of Economics and Statistics, Vol. 66(No. 4), pp. 457-482.

Salter, W. E. G. 1960. Productivity and Technical Change. Cambridge University Press.

Santarelli, Enrico, \& Sterlacchini, Alessandro. 1990. Innovation, Formal vs. Informal R\&D, and Firm Size: Some Evidence from Italian Manufacturing Firms. Small Business Economics, Vol. 2, pp. 223-228.

Schumpeter, Joseph. 1934. The Theory of Economic Development. Cambridge: Harvard University Press, 1st edn. 1912.

Schumpeter, Joseph. 1942. Capitalism, Socialism and Democracy. New York: Harper and Brothers.

Sterlacchini, Alessandro. 1994. Technological Opportunities, Intra-Industry Spillovers and Firm R\&D Intensity. Economics of Innovation and New Technology, Vol. 3, pp. 123-137.

Tobin, James. 1958. Estimation of Relationships for Limited Dependent Variables. Econometrica, Vol. 26(No. 1), pp. 24-36.

Winter, Sidney G. 1984. Schumpeterian Competition in Alternative Technological Regimes. Journal of Economic Behavior and Organization, Vol. 5(Issues 3-4), pp. 287-320. 